\title{
INCENTIVE SCHEMES AND EMPLOYEES' PRODUCTIVITY IN PRIVATE ORGANISATIONS IN NIGERIA
}

\author{
https://doi.org/10.47743/jopafl-2021-22-10
}

\author{
Olalekan Eyitayo AJIBADE \\ Department of Public Administration \\ Federal Polytechnic, Ilaro, Ogun State Nigeria \\ olalekan.ajibade@federalpolyilaro.edu.ng \\ Oluwaseun Adewale SALAKO \\ Department of Public Administration \\ Federal Polytechnic, Ilaro, Ogun State Nigeria \\ oluwaseun.salako@federalpolyilaro.edu.ng
}

\begin{abstract}
The aim of the paper is to examine the effect of incentives schemes on employees' productivity in private organisations in Nigeria. The paper also researched on the useful information that would help private organisations apply and sustain various incentive schemes available. In achieving the objectives of this study, data were sourced from both primary and secondary sources. Primary sources consist of books and relevant journals while secondary data were gathered from cases from Dangote Cement Plc., Ibese. The findings were that a number of incentives (monetary, tangible and non tangible non-monetary) play prominent and significant roles in enhancing employees' productivity in private organisations in Nigeria. The paper recommends that management should come up with short term employee attraction and retention mechanisms. The company cannot go far with unmotivated employees.

Keywords: Employee Productivity, Dangote Cement, Incentive Schemes, Monetary, Non-monetary
\end{abstract}

\section{Introduction}

Employees occupy a strategic role and position in any organization. They are responsible for converting inputs to productive outputs. Since they are the key to the productive outputs, they ought to be effectively and adequately compensated for their labour. Taking cues first from the Biblical expression that a labourer deserves his wages; and secondly bearing in mind that the reward for labour, a factor of production is "wages", it becomes logical that employees be adequately and fairly compensated if they are to be motivated to increase productivity in any organization be it the organized private sector or public sector. Drucker (1980:230) believes that "the work of management is to make people productive” so as to achieve superior performance, and gain a competitive edge in the globalized arena through effective compensation packages. Drucker's belief is anchored on productivity, performance, motivation quality and service in managing people in every organization. This emphasis is often captured in organizational mission statements and goals. Two major components of compensation are open to management: the financial (material) and the non-financial (non-material) components. According to Milkovich and Newman (2008) incentive schemes (short-term and long-term) constitute part of the financial components of employee compensation. Incentive schemes tie pay increase to performance and have been used by organizations worldwide with remarkable success. For example, Niagara Frontier Transit Metro System, Inc, New York uses the safe Driver 
Awards for bus operators who have experienced accident free driving during the previous year. Recipients are awarded incentives ranging from pins through watches to bonds, extra weeks' vacation, and certificates. The incentives are given at an annual luncheon held for recipients. The best of the best ${ }^{\text {te }}$ incentive is given to employees based on an individual's performance evaluation and extraordinary service in line with the mission statement of Montgomery country division of Transportation Services, Rockville, Maryland, USA. In Thailand, the government offered public doctors incentives to work in rural and remote areas (Hongoro and Normand, 2002). The Human Development Report, (2001) showed that Korea and Taiwan used incentive schemes to encourage their diasporas to return than encouraging them to invest at home. They upgrade their research institutions as a way to attract returnees. The commissions responsible for this exercise provide better working conditions help with housing and children's schooling. In Colombia, government attempted to correct the distortional problems of donor-driven salary top ups and project implementation units and through its "Rectangular Strategy", increased civil service pay between $10-15 \%$ per annum in priority areas. All the incentive schemes as highlighted above motivate employees and fielded positive results on the organizations and the economy. It is believed that if Nigerian organizations too offer effective incentive schemes to their employees, they will be motivated hence increase in productivity.

Incentive provides a platform through which firms can motivate their employee's to improve their employee's productivity, scholars like Pouliakas, (2008); Pinar (2008); Arnolds and Venter, (2007) have all carried out research into monetary and non-monetary incentive and how they affect organizations. Incentive programs are put in place by organizations to reward and compensate exceptional employee's productivity (Schiller, 1996). These packages could come in financial or non-financial forms but its objective is to compel the employee to show more efforts in any given task. Incentives are forces that cause employee's to behave in a certain way on any given day usually as hard as possible. However it is noteworthy that incentives are designed to get maximum employee's productivity from the employee's and help retain the most productive and performing employee's (Arnold, 2013). Organizations must ensure they use the best incentives to get the required result from their employee's. Incentives are instrumental drive towards employee motivation and employee's productivity as it has great benefits and high potential to motivate workers to put in their best in any given task (Condly et al. 2003). Delvecchio and Wagner (2007) observed the effect of different incentives on salespeople and concluded that younger salespeople react more dramatically and positively with higher intrinsic motivation when paid on plans with higher incentive proportion. Ojokuku (2011) also identified the effect of financial incentives on information and communication technology professionals. Profit sharing plans, premium pay and cash bonus are the types of financial benefits enjoyed by these professionals which enhanced their motivation to work.

Studies abound in the area of incentive management strategies as highlighted above, but most of the works cited above were all done in the western world and considering the role of culture in determining what motivates an individual, as a result one could say there is gap in literature that addresses the issue of incentive management practices and employees performance with respect to our geographical location and also having in mind the peculiarity of the industry being investigated. It is as a result of this gap 
that the researcher seeks to examine the effect of incentives schemes on worker's productivity in an organisation using Dangote Cement Plc. Ibese as a study

\section{Hypotheses}

The following hypotheses stated to achieve the objectives of the study.

i. There is a significant relationship between incentive schemes and workers' productivity at Dangote Cement Plc. Ibese.

ii. There is no significant relationship between incentive schemes and workers' productivity at Dangote Cement Plc. Ibese.

\section{Literature review}

Concept of Incentives

National Productivity Council (2014) defined incentive as a measure stimulating human effort, whereby employees are driven to put in their best. Matocchio (2006) in Tongo (2006) encapsulated the concept of incentives defining it as compensation, other than basic wages and salaries that fluctuates according to employees' attainment of some standard, such as pre-determined benchmark, individual or group goals or organizational earning. Generally, incentives are variable payments made to employees on the basis of the amount of output or results attained (Banjoko, 2006). According to Tongo (2006), the use of performance incentives dates back to the era of scientific management movement, championed by Frederick Taylor in the 20th century, and ever since then, the private sector has employed the use of incentives as a method to raise the productivity of their employees. Incentive provision is meant to drive employee to go extra mile to achieve better result. It is a tool that can be engaged by any employer of labour, whether public or private employer and regardless of the type of task involved. However, amongst the various forms of incentive, an employer is at liberty to engage anyone considered suitable and affordable. Being a vocation and profit driven, real estate management practitioners engage incentive provision to motivate workers and increase performance.

\section{Types of Incentives}

Different classifications of incentives have been recognized in literature. The National Productivity Council classified incentives into non-financial, financial and semifinancial. Non-financial incentive schemes are those for which no form of monetary benefit, direct or indirect is attached to it, for example, recognition, praise for achievement or hanging a picture on the wall of best employee of the month, a plaque for excellent service and the like. However this is sufficient enough only to supplement the financial incentives as non-financial incentives are not motivation enough as standalone incentives (NPC, 2015). Semi-financial incentives are those schemes that have some indirect monetary benefit but not directly linked with wages. Examples include promotions, company car and the likes. Financial incentives are the most popular form of incentives and have the benefit of option value; meaning that employees can do whatever they wish with it, which gives it an edge over other forms of incentives (Jeffrey and Schaffer, 2007). Moreover, Milgrom and Roberts (1992) state that incentives could be awarded to individuals as well as groups. Under the individual incentive plan, each employee is rewarded based on his individual performance. Individual incentive has been found to be substantially more effective than the group incentives (NPC, 2015). Group incentives compensate a number of workers that are part of a team for their combined effort in 
achieving the desired outcome. Group incentives are a way of instilling a shared sense of collective responsibility with the end game of achieving superior and above average performance in an organization (Azasu, 2003). Short term incentives include annual bonuses and commission based on performance in the period immediately preceding its award while long term incentive refers to incentives that are not realized until some time period has elapsed (Azasu, 2003). Examples include, contribution to pension funds, nonvested options in which case the employee has to remain with the company for a set period of time in order to realize the options and if the employee leaves the company before the time period elapsed he loses the right to the options (Lazear, 1999). Overall, there is very little doubt that incentives have a positive impact on the productivity levels in an organization. Schraeder and Becton (1998) examine the impact of three incentive programs on employee productivity and found a positive correlation between incentives and employee productivity. The authors concluded that firms in the service industries that offer aggressive incentive structures create a hunger in the organization whereas those that provide comfortable base salaries foster complacency.

\section{Concept of Incentive Scheme}

Incentive schemes as defined by Graffin and Ebert (1993), are special pay programs designed to motivate high performance. Incentive schemes attempt to link at least a portion of pay to job performance to encourage higher productivity. Incentives, as often called, should be aligned with the behaviors that help achieve organizational goals or performance. Hartman, Kurtzand and Moser (1994) state that incentives are one technique by which

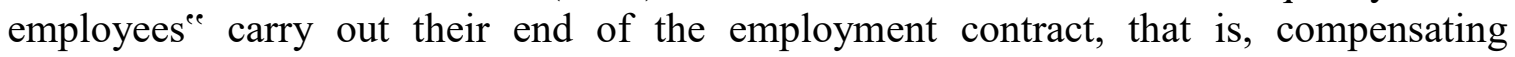
employees for their efforts. In general, an incentive scheme (payment or programme) is any compensation that has been designed to recognize some specific accomplishment on the part of an employee. It is expected that the prospect of the incentive payment will trigger the desired performance behaviour in the employee. Incentive schemes as defined by Graffin and Ebert (1993), are special pay programmes designed to motivate high performance. Incentive schemes attempt to link at least a portion of pay to job performance to encourage higher productivity. Incentives, as often called, should be aligned with the behaviours that help achieve organizational goals or performance. Incentives are either individual or group (organization wide). In this study, financial incentives are designed to motivate employees to improve their performance - to increase effort and output and by producing better results expressed in such terms as objectives for profit, productivity, sales turnover, cost reduction, quality customer service and on time delivery. This financial compensation provides extra money for achievement in terms of contribution or output. The emphasis in financial compensation is on equity, in the sense of paying people according to their just deserts. Incentive schemes relate compensation to productivity. A primary purpose of an incentive scheme is to encourage greater productivity from individuals and work groups. The assumption usually made by management is that money or cash alone may not motivate employees. In designing incentive schemes, output standards should be established. The standard is a measure of work that an average, welltrained employee, working at a normal pace, should be able to accomplish in a given period of time. In addition to motivating employees to increase their level of productivity, incentive schemes may reduce turnover among good performers or productive workers. 
Incentive schemes are also cost effective because of savings that often resulted from productivity improvements.

\section{Purpose of Incentive Schemes}

According to Caruth, Middlebrook and Frank (1982), the general purpose of incentive schemes is to increase productivity in the organization. By relating compensation to output, an employer is attempting to induce workers to turn out a greater volume of work thereby lowering the cost of producing a single unit of output. Specifically, the purpose of incentives to both an employee and the organization is to:

Improve motivation

Tie pay to performance

Recognize differences in employee performance

Increase competition among employees

Attract and retain productive employees

Reduce absenteeism

Reduce idle time

Reduce or control costs

Utilize equipment more effectively

Relate increases in compensation to increases in productivity

\section{Concept of Employee's Productivity}

In economics, productivity is the ratio of what is produced to what is required to produce. It is the measure of production efficiency over a given period of time. To the engineer; productivity means new technology, machines and equipment, measurement and controls. To a business manager, productivity has various meanings including effectiveness and efficiency. This is because in management there are no measurable units of output, no productivity function and the non-existence of an effective data base. Agoro (1991) uses the word productivity to mean the output per unit of factor input over a given period of time. It is the ratio between the output of wealth produced and the input of resources consumed in the process of production. Adekoya (1991), agree emphasizing that productivity is a measure of how well labour resources/skills are brought together in a firm and utilized for accomplishing a set result. Efficiency in production is measured by the ratio of input to output. Efficiency in the utilization of labour in an organization involves obtaining the highest level of performance from the employees with the least expenditure in labour wages. The International Labour Organization (ILO) as cited in Prokopenko (1992) defined productivity to be the effective and efficient utilization of all resources; capital, labour, material, energy, information and time. In this paper, Nwasike's (1991) definition is used, as a working definition. She defined productivity as: The efficiency with which inputs are used to produce the desired output ${ }^{\mathrm{ee}}$. Earlier, Udo-Aka (1983) defined productivity as a measure of overall production efficiency, effectiveness and performance of the individual organization. Akerele (1991) contends that productivity is the "measure of how well a nation's resources are utilized for accomplishing a set of results...reaching the highest level of performance with the least expenditure of resources". This is a synthesized definition of productivity. Akerele (1991) further maintained that: Productivity is an attitude of the mind. It is the mentality of progress and constant improvement of that which exists. It is the certainty of being able to change that which exists. It is the certainty 
of being able to do better today than yesterday. It is the will to improve on the present situation, no matter how good it may look. It is the constant adaptations of economic conditions. It is the continued effort to apply new techniques and it is the faith in human capabilities. From the above, it is clear that the applicability of the productivity concept to every sphere of human endeavour remains constant, the relevance and centrality of productivity to human existence can never be denied. This paper assumes that productivity is effectiveness, efficiency, performance and growth. Productivity improvement, in the words of Prokopenko (1998) "is not just doing things better. It is doing the right things better”. Productivity improvement therefore depends on upon how successfully the main factors of socio-production systems that influence productivity are identified and used. Nworah (1991) had earlier contended that productivity improvement was the increase in output (goods and services) got from a given input by better management and utilization of resources, including human resources. It does not necessary mean getting them to work smarter. Work is generally easier when productivity improvement takes place. Productivity improvements are obtained through improved product or system design, use of improved machinery and equipment, improved skill and effectiveness of the workers and increased production volume and levels. Productivity improvement is important for this paper because it makes it easier to improve the standard of living of any nation hence its applicability to the Nigerian business situation.

\section{Incentive Schemes and Worker's Productivity at Organisations}

Productivity is usually defined as the ratio of inputs to outputs. It essentially measure how efficiently production inputs such as labour and capital are being used to produce a given level of output (Krugman, 1994). Okoye and Ezejiofor (2013) opined that organizational productivity is the measure of how well an organization functions and also an indication of efficiency and competition. Also it is a measure of how well resources are brought together and utilized for accomplishing set objectives (Mali, 2008 in Okoye \& Ezejiofor, 2013). Productivity is a global concern, which has inseparable ties to the longevity of the organization (Druckman, Singer \& Van Cott 1997 in Arraya, 2013). It is the key for survival in the cut-throat world of business and gives the organization a key competitive advantage above its peers when it is able to do more with less (Weaver, 2008 in Arraya, 2013). The baseline for economic productivity of an organization is the strength and quality of human capital. Human capital refers to the skills, abilities, competencies and qualities of an organization's employees. It comprises of the knowledge and expertise employees apply to produce products and services and to the operations of the organization, its equipment and machineries (Weaver, 2008 in Arraya, 2013). When human capital is adequately motivated, it leads to enhancement in productivity and service delivery. Boela (2005) states that, incentives are offered in order to focus the employee's attention to the business objectives of the employer, and add that they are normally used to stimulate performance and particularly to increase sales and control costs. George (2002) says that incentives work best alongside a good pay scheme, good working conditions and other good management practices, such as performance management, appraisals and appropriate communication and training programmes. According to study financial incentives improved performance over 30 per cent compared with those who did not get incentives. Also other researchers have conducted similar empirical studies and found that 
performance increase in groups with financial bonus systems whereas in control groups' performance usually stays at the same level.

Connell (1992), Furthermore Locke et al. (1980), compared individual pay incentives, job enrichment and employee participation and found that financial rewards are most efficient. Holtmann (2005) contends that if incentive schemes are to be effective, they must be accepted by those they target. To assure acceptance, they should be in line with two principles, i.e. fairness and transparency, according to which employees' judge their remuneration. According to the author, fairness and transparency are the two most important requirements for staff incentive schemes in business organizations. Pertaining to fairness as Holtmann (2005) mentioned that the goals or reference standards set out for employees must be attainable, staff members who perform better than others should receive higher compensation and the compensation system should reflect the hierarchical levels within the organization. According to Milkovich \& Newman (2005), bonus pay is a financial reward given to employees in addition to their fixed compensation. Bonus pay is the most common form of cash incentive. Bonuses can be accrued and paid out at different intervals, such as monthly, quarterly, or annually. Bonus sizes vary between $10 \%$ and $50 \%$ of the total pay. This pay plan is also apparently based on individual performance, but bonuses do not increase employees' base pay and therefore are not permanent. In most cases, staff incentive schemes are employed to enhance productivity. To analyze the present staff productivity and thus to appraise the potential for improvement, we could compare our staff in terms of productivity (e.g. in the number of transactions of counter sales staff or in the number of stock spare parts of parts sales supervisor, or in the capacity of branch managers to develop their branch and staff). If there were high disparities, which can at least partly be explained by disparities in staff motivation, we could further ask how staff incentives would contribute to a higher overall performance of staff (Carolina, 2010). In accordance with productivity is the sustained rate at which employees are achieving the agreed minimum outputs of work as agreed to within an organization, it is the rate at which goods are produced, especially in relation to the time, money and workers required to produce them. Holtmann and Grammling (2005) conducted a preliminary research on 86 institutions and found that $83 \%$ of the total respondents agreed on the fact that incentive schemes had a high effect on increasing the productivity of employees. They also said that many managers use incentive schemes to try to improve productivity. Thus, staff incentive schemes have powerful effects on the staff productivity of the organization and thereby are able to boost staff performance.

Non-monetary incentives are non-cash benefits given by company to employees to retain, reward and motivate them for their excellent job performance (Woodruffe, 2006). Nonmonetary incentives are deemed more valuable than monetary incentives as it shows respect and appreciation on employees' accomplishment (Gale, 2002). In the research of Nelson (2001) which is conducted in United States showed that there is a strong bond of relationship between non-monetary incentives and employees' job engagement. According to Houston (2000), Non-financial incentives come in many forms such as gifts, rewards, travel. Some are more tangible than others since they are visible and/or can be compared to financial benefits. Less tangible incentives relate for instance to work flexibility, independence of working, recognition of one's work, the possibility of advancement. The value of non-financial material incentives seems to be perceived as a function of psychological processes. 


\section{Methodology}

The paper adopts both qualitative and quantitative research methods. In achieving the objectives of the study, data were sourced from secondary materials, i.e. relevant books, journals and internet materials whoever, the population for this study was drawn from staff of Dangote Cement Plc, Ibese.

\section{Results and discussion}

\section{Data Presentation and Analysis. Response Rate}

The target respondents in the study were the staff of Dangote Cement Factory Ibese, Ogun State. A total of 196 questionnaires were administered, 196 were filled and returned, which represent $100 \%$ response. The high response rate recorded by the researcher could be attributed to the data collection procedures for instance, the researcher pre-notified the potential participants for the survey, the researcher administered the questionnaire with the help of the units head of the agency and follow up calls were also made to clarify queries as well as to prompt the respondents to fill the questionnaire. These methods facilitated the whole process of data collection hence the high response rate. The response rate is represented in Table 1.

Table 1 Response Rate

\begin{tabular}{|c|c|c|}
\hline $\begin{array}{c}\text { Questionnaire } \\
\text { Distributed }\end{array}$ & Questionnaire Retrieved & \% Response \\
\hline 196 & 196 & $100 \%$ \\
\hline
\end{tabular}

Source: Field Survey (2021)

\section{Analyses of Responses to the Questionnaire}

The second section of the questionnaire focuses on the respondent's view on Incentive Schemes and Workers' Productivity. Therefore, the analyses of the research questions in accordance with the respondents' opinion are presented hypothesis by hypothesis as shown below:

Hypothesis 1: There is a significant relationship between incentive schemes and workers' productivity at Dangote Cement Plc. Ibese.

The questions (on the questionnaire schedule) relating to this hypothesis are:

Question 1: Bonuses are paid fairly for extra work, efficiency and achievements.

Table 2 Bonuses paid for Extra Work Done

\begin{tabular}{|c|c|c|}
\hline Responses & Frequency (f) & Percentage (f) (\%) \\
\hline Strongly Agree & 85 & 43 \\
\hline Agree & 65 & 33 \\
\hline Undecided & 30 & 15 \\
\hline Disagree & 10 & 5 \\
\hline Strongly Disagree & 6 & 4 \\
\hline Total & $\mathbf{1 9 6}$ & $\mathbf{1 0 0}$ \\
\hline
\end{tabular}

Source: Field Survey (2021) 
As shown in table 2, out of 196 respondents sampled, 43\% of the respondents strongly agreed that bonuses are paid for extra work done in the company; 33\% agree while $15 \%$ of them were undecided to the statement and 5\% disagree with another $4 \%$ strongly disagreeing to the statement. The analysis shows that on average, $43 \%$ strongly agreed that bonuses are paid for extra work done at Dangote Cement Plc.

Question 2: The Company usually provides bonuses for all its employees' according to the job grade.

Table 3 Bonuses and Job Grade

\begin{tabular}{|c|c|c|}
\hline Responses & Frequency (f) & Percentage (f) (\%) \\
\hline Strongly Agree & 92 & 47 \\
\hline Agree & 54 & 27 \\
\hline Undecided & 23 & 12 \\
\hline Disagree & 17 & 9 \\
\hline Strongly Disagree & 10 & 5 \\
\hline Total & $\mathbf{1 9 6}$ & $\mathbf{1 0 0}$ \\
\hline
\end{tabular}

Source: Field Survey (2021)

As shown in table 3, out of 196 respondents sampled, 47\% of the respondents strongly agreed that bonuses are paid according to workers' job level; $27 \%$ of the respondents agree while $12 \%$ were undecided. $9 \%$ of the respondents disagree to the statement and 5\% strongly disagree. By this analysis, it shows that workers are paid at Dangote Cement Plc. in line with their job grades.

Question 3: The management of the company is fair in the implementation of profit sharing Scheme

Table 4 Profit Sharing Scheme

\begin{tabular}{|c|c|c|}
\hline Responses & Frequency (f) & Percentage (f) (\%) \\
\hline Strongly Agree & 25 & 13 \\
\hline Agree & 25 & 13 \\
\hline Undecided & 23 & 12 \\
\hline Disagree & 50 & 25 \\
\hline Strongly Disagree & 73 & 37 \\
\hline Total & 196 & 100 \\
\hline
\end{tabular}

Source: Field Survey (2021)

As shown in table 4, out of 196 respondents sampled, 37\% of the respondents strongly disagreed that the management of the company is fair in the implementation of profit sharing scheme $25 \%$ of the respondents disagree while $12 \%$ were undecided. $13 \%$ of the respondents agree to the statement and 13\% strongly agree. By this analysis, it shows that the management of Dangote Cement Plc. do not implement profit sharing scheme on workers.

Question 4: Management recognizing employees whose efforts make a difference.

Table 5 Recognition of Workers

\begin{tabular}{|c|c|c|}
\hline Responses & Frequency (f) & Percentage (f) (\%) \\
\hline Strongly Agree & 80 & 41 \\
\hline Agree & 50 & 25 \\
\hline Undecided & 30 & 15 \\
\hline
\end{tabular}




\begin{tabular}{|c|c|c|}
\hline Disagree & 16 & 8 \\
\hline Strongly Disagree & 20 & 11 \\
\hline Total & 196 & 100 \\
\hline
\end{tabular}

Source: Field Survey (2021)

As shown in table 5, out of 196 respondents sampled, $41 \%$ of the respondents strongly agree to the statement that the management of the company recognizes employees whose efforts makes a difference; $25 \%$ of the respondents agree while $15 \%$ were undecided; $8 \%$ of the respondents disagree to the statement and $11 \%$ strongly disagree. By this implication, it shows that the management of Dangote Cement Plc., recognizes employees whose efforts makes a difference.

Question 5: Incentive travel to boost the morale of individual or team for work is well done

Table 6 Incentive Travel for Workers

\begin{tabular}{|c|c|c|}
\hline Responses & Frequency (f) & Percentage (f) (\%) \\
\hline Strongly Agree & 90 & 46 \\
\hline Agree & 50 & 25 \\
\hline Undecided & 15 & 8 \\
\hline Disagree & 21 & 11 \\
\hline Strongly Disagree & 20 & 10 \\
\hline Total & 196 & 100 \\
\hline
\end{tabular}

Source: Field Survey (2021)

Table 6 reveals that $46 \%$ of the respondents strongly agreed that the company makes provision for incentive travels for workers to so as to boost their morale or for team work well done; $25 \%$ of the respondents agreed while, $08 \%$ was undecided, $11 \%$ of the respondents disagreed and 10\% strongly disagreed. Majority of the respondents strongly agreed that Dangote Cement Plc., makes provision for incentive travels for workers to so as to boost their morale or for team work well done.

Question 6: There are enough promotion possibilities to stimulate me to higher performance.

Table 7 Promotion for Higher Performance

\begin{tabular}{|c|c|c|}
\hline Responses & Frequency (f) & Percentage (f) (\%) \\
\hline Strongly Agree & 88 & 45 \\
\hline Agree & 55 & 28 \\
\hline Undecided & 30 & 15 \\
\hline Disagree & 13 & 7 \\
\hline Strongly Disagree & 10 & 5 \\
\hline Total & $\mathbf{1 9 6}$ & $\mathbf{1 0 0}$ \\
\hline
\end{tabular}

Source: Field Survey (2021)

Table 7 reveals that $45 \%$ of the respondents strongly agreed that there are enough promotion possibilities to stimulate me to higher performance; $28 \%$ of the respondents agreed while, $15 \%$ was undecided, $07 \%$ of the respondents disagreed and $05 \%$ strongly disagreed. Majority of the respondents strongly agreed that at Dangote Cement Plc, there are enough promotion possibilities to stimulate me to higher performance.

Question 7: When an employee performs well consistently they are promoted to next level. 
Table 8 Consistency and Next Level Promotion

\begin{tabular}{|c|c|c|}
\hline Responses & Frequency (f) & Percentage (f) (\%) \\
\hline Strongly Agree & 35 & 18 \\
\hline Agree & 25 & 13 \\
\hline Undecided & 35 & 18 \\
\hline Disagree & 45 & 23 \\
\hline Strongly Disagree & 56 & 28 \\
\hline Total & $\mathbf{1 9 6}$ & $\mathbf{1 0 0}$ \\
\hline
\end{tabular}

Source: Field Survey (2021)

Table 8 reveals that $18 \%$ of the respondents strongly agreed that employees are promoted to the next level when they consistently perform well; $13 \%$ of the respondents agreed while, $18 \%$ was undecided, $23 \%$ of the respondents disagreed and $28 \%$ strongly disagreed. From this, majority of the respondents strongly disagree to the statement.

Question 8: A positive working conditions is important for me to perform well on my job.

Table 9 Working Conditions and Performance

\begin{tabular}{|c|c|c|}
\hline Responses & Frequency (f) & Percentage (f) (\%) \\
\hline Strongly Agree & 92 & 47 \\
\hline Agree & 75 & 38 \\
\hline Undecided & 29 & 15 \\
\hline Disagree & 00 & 00 \\
\hline Strongly Disagree & 00 & 00 \\
\hline Total & $\mathbf{1 9 6}$ & $\mathbf{1 0 0}$ \\
\hline
\end{tabular}

Source: Field Survey (2021)

Table 9 shows that, $47 \%$ of the respondents strongly agreed that a positive working condition is important for me to perform well on my job; $38 \%$ of the respondents agreed while $15 \%$ of the respondents were undecided, $00 \%$ of them disagreed and $00 \%$ strongly disagreed. These responses present heavy evidence that positive working conditions aids in the performance of workers.

Hypothesis II: There is no significant relationship between incentive schemes and workers' productivity at Dangote Cement Plc. Ibese.

The questions (on the questionnaire schedule) relating to this hypothesis are:

Question 9: The work environment can elicit greater commitment in me to perform my best.

Table 10 Work Environment and Commitment

\begin{tabular}{|c|c|c|}
\hline Responses & Frequency (f) & Percentage (f) (\%) \\
\hline Strongly Agree & 75 & 38 \\
\hline Agree & 58 & 30 \\
\hline Undecided & 29 & 15 \\
\hline Disagree & 16 & 08 \\
\hline Strongly Disagree & 18 & 09 \\
\hline Total & $\mathbf{1 9 6}$ & $\mathbf{1 0 0}$ \\
\hline
\end{tabular}

Source: Field Survey (2021)

From Table 10, 38\% of the respondents strongly agreed that work environment can elicit greater commitment of workers at Dangote Cement Plc; 30\% of the respondents 
agree; $15 \%$ of the respondents were undecided, $08 \%$ of the respondents disagreed and $09 \%$ strongly disagreed. The analysis indicates that most of the respondents agreed that work environment can elicit greater commitment of workers at Dangote Cement Plc.

Question 10: The Company is committed to the training and development of its employee.

Table 11 Training and Development of Workers

\begin{tabular}{|c|c|c|}
\hline Responses & Frequency (f) & Percentage (f) (\%) \\
\hline Strongly Agree & 58 & 30 \\
\hline Agree & 75 & 38 \\
\hline Undecided & 29 & 15 \\
\hline Disagree & 18 & 09 \\
\hline Strongly Disagree & 16 & 08 \\
\hline Total & $\mathbf{1 9 6}$ & $\mathbf{1 0 0}$ \\
\hline
\end{tabular}

Source: Field Survey (2021)

Table 11 shows that, 30\% of the respondents strongly agreed that Dangote Cement Plc, is committed to the training and development of its employee; $38 \%$ of the respondents agree; $15 \%$ of the respondents were undecided, $09 \%$ of the respondents disagreed and $08 \%$ strongly disagreed. The analysis indicates that most of the respondents agreed that training and development of workers is a priority at Dangote Cement Plc.

Question 11: The company provides me with skills and knowledge that will benefit my future career.

Table 12 Skills and Knowledge Acquisition

\begin{tabular}{|c|c|c|}
\hline Responses & Frequency (f) & Percentage (f) (\%) \\
\hline Strongly Agree & 94 & 48 \\
\hline Agree & 75 & 38 \\
\hline Undecided & 10 & 05 \\
\hline Disagree & 7 & 04 \\
\hline Strongly Disagree & 10 & 05 \\
\hline Total & $\mathbf{1 9 6}$ & $\mathbf{1 0 0}$ \\
\hline
\end{tabular}

Source: Field Survey (2021)

Table 12 shows that, $48 \%$ of the respondents strongly agreed that the company provides them with skills and knowledge that will benefit their future career; $38 \%$ of the respondents agree; $05 \%$ of the respondents were undecided, $04 \%$ of the respondents disagreed and $05 \%$ strongly disagreed. The analysis indicates that most of the respondents agreed that skills and knowledge acquired at Dangote Cement Plc, will be beneficial to them in the future.

Question 12: Performance based incentive scheme encouraged me to exert more effort and improve my productivity.

Table 13 Incentive Schemes and Productivity

\begin{tabular}{|c|c|c|}
\hline Responses & Frequency (f) & Percentage (f) (\%) \\
\hline Strongly Agree & 99 & 50 \\
\hline Agree & 59 & 30 \\
\hline Undecided & 10 & 05 \\
\hline Disagree & 20 & 11 \\
\hline Strongly Disagree & 08 & 04 \\
\hline
\end{tabular}


Source: Field Survey (2021)

Table 13 shows that, $50 \%$ of the respondents strongly agreed that Performance based incentive scheme encouraged me to exert more effort and improve their productivity; $30 \%$ of the respondents agree; $05 \%$ of the respondents were undecided, $11 \%$ of the respondents disagreed and $04 \%$ strongly disagreed. By this analysis, majority of the respondents strongly agree that performance based incentive scheme encourages them to put in more efforts to their duties.

Question 13: Employee adherence to the expected standard is a key indicator in measuring the performance.

Table 14 Employees' Adherence to Standard

\begin{tabular}{|c|c|c|}
\hline Responses & Frequency (f) & Percentage (f) (\%) \\
\hline Strongly Agree & 88 & 44 \\
\hline Agree & 59 & 30 \\
\hline Undecided & 19 & 10 \\
\hline Disagree & 20 & 11 \\
\hline Strongly Disagree & 10 & 05 \\
\hline Total & $\mathbf{1 9 6}$ & $\mathbf{1 0 0}$ \\
\hline
\end{tabular}

Source: Field Survey (2021)

From Table 14, 44\% of the respondents strongly agreed that employee adherence to the expected standard is a key indicator in measuring the performance; $30 \%$ of the respondents agree; $10 \%$ of the respondents were undecided, $11 \%$ of the respondents disagreed and $05 \%$ strongly disagreed. The analysis indicates that most of the respondents strongly agreed that employee adherence to the expected standard is a key indicator in measuring the performance.

Question 14: Employees' attitude and commitment have positive influence on company's overall performance.

Table 15 Employees’ Adherence to Standard

\begin{tabular}{|c|c|c|}
\hline Responses & Frequency (f) & Percentage (f) (\%) \\
\hline Strongly Agree & 88 & 44 \\
\hline Agree & 59 & 30 \\
\hline Undecided & 19 & 10 \\
\hline Disagree & 20 & 11 \\
\hline Strongly Disagree & 10 & 05 \\
\hline Total & $\mathbf{1 9 6}$ & $\mathbf{1 0 0}$ \\
\hline
\end{tabular}

Source: Field Survey (2021)

From Table 15, 44\% of the respondents strongly agreed that employees' attitude and commitment have positive influence on company's overall performance; $30 \%$ of the respondents agree; $10 \%$ of the respondents were undecided, $11 \%$ of the respondents disagreed and $05 \%$ strongly disagreed. The analysis indicates that most of the respondents strongly agreed that employees' attitude and commitment have positive influence on company's overall performance. 
Question 15: Employees are motivated to work collectively towards achieving common goals.

Table 16 Employees’ Motivation and Common Goals

\begin{tabular}{|c|c|c|}
\hline Responses & Frequency (f) & Percentage (f) (\%) \\
\hline Strongly Agree & 85 & 43 \\
\hline Agree & 65 & 33 \\
\hline Undecided & 30 & 15 \\
\hline Disagree & 10 & 5 \\
\hline Strongly Disagree & 6 & 4 \\
\hline Total & 196 & 100 \\
\hline
\end{tabular}

Source: Field Survey (2021)

As shown in table 5.16, out of 196 respondents sampled, 43\% of the respondents strongly agreed that employees are motivated to work collectively towards achieving common goals; $33 \%$ agree while $15 \%$ of them were undecided to the statement and 5\% disagree with another $4 \%$ strongly disagreeing to the statement. The analysis shows that on average, $43 \%$ strongly agreed that employees are motivated to work collectively towards achieving common goals.

\section{Discussions of Findings}

This study examines the effect of incentive schemes on worker's productivity in an organisation using Dangote Cement Plc. Ibese. In achieving the objectives of the study, research hypothesis were formed and tested using the Chi -square (X2 ) analytical techniques. The result of the first test showed there is no significant relationship between incentive schemes and workers' productivity at Dangote Cement Plc. Ibese. This was further supported when $43 \%$ of the respondents sampled strongly agreed that bonuses are paid for extra work done in the company. The second test showed that there is no significant relationship between incentive schemes and workers' productivity at Dangote Cement Plc. Ibese. This was also further supported when $28 \%$ of the respondents strongly disagreed that employees are promoted to the next level when they consistently perform well.

\section{Conclusion}

The study looked at the interplay between incentive schemes and workers' productivity in Organisations using Dangote Cement Plc as a study. The study concluded that a number of incentives (monetary, tangible and non tangible non-monetary) play a prominent and significant roles in enhancing employees productivity in organisations. Meanwhile, the present study is limited to incentive schemes at Dangote Cement Plc; further studies in this area should increase the sample size, attention should also be giving to the role of incentive packages on employees' attitudes to work within the group. In addition, the method of data analysis used in this research work was limited to the use of one study area; further studies can engage some more companies or organisation to arrive at findings that can be generalized. 


\section{Recommendations}

Experience has shown that organizations that provide effective incentives are more likely to have satisfactory job performance from employees. Based on the findings and conclusions of this study, there are recommendations forwarded for better improvement of employees productivity;

i. Management should come up with short term employee attraction and retention mechanisms. The company cannot go far with unmotivated employees. If employees are not doing their best to the company and they don't consider that the company as the best of all possible organizations for which to work, implies employees loosing motivation and commitment to the work and the company.

ii. Performance goals should be clearly defined and regular reviewing of the performance of employees against performance target standards and recognize accordingly.

iii. Management should seek and obtain feedback on the measure of employee satisfaction survey on how employees perceive incentives. Feedback combined with appropriate incentive schemes produce the strongest effect on employee performance after identifying the incentive schemes which motivates employees most.

iv. The management needs to develop rightful incentive schemes that include a mix of both financial and non-financial incentives. Incentive type would influence performance differently when applied to the employee. Managers will therefore need to strategically identify incentives that lead to high performance among the employees.

\section{References}

1. Agoro, R. O. (1991). Productivity, the Panacea to Industrial Growth, Economic Fertility and National Greatness. Proceedings of a National Conference on Productivity, Abuja.

2. Armstrong, M. (2003). A handbook of Human Resource Management. 9th edition, London: Kogan Page.

3. Arnold, A. (2013), The Best Employee Incentives; Demand Media, Houston Chronicles, Texas

4. Arnolds, C, \& Venter D. (2007). The strategic importance of motivational rewards for lower-level employees in the manufacturing and retailing industries. SA Journal of Industrial Psychology, 33(3), 15-23. https://hdl.handle.net/10520/EJC186814

5. Arraya, M. \& Pellissier R. (2013) Productivity Measurement in a Sports Organization Southern African Business Review 17 (1) 98-127. https://hdl.handle.net/10520/EJC135843

6. Azasu, S. (2004). Using Pay and Benefits in a Swedish Real Estate Firm. Retrieved from http://eres.scix.net/data/works/att/db82.content.00379.pdf

7. Banjoko, S. (2006) Managing Corporate Reward Systems, Lagos: Pumark Nigeria Limited Companies, Inc.

8. Condly, S.J, Richard E. Clark \& Harold D. Stolovitch, (2003). The Effects of Incentives on Workplace Performance: A Meta-analytic Review of Research Studies. Performance Improvement Quarterly, 16(3) , 46-63 https://doi.org/10.1111/j.1937-8327.2003.tb00287.x

9. Del Vecchoi, S. \& Wagner, J. (2007). Motivation and Monetary Incentives. Journal of Management and Marketing research. 7(1), 1- 13

10. Drucker, P. (1980), Managing in turbulent times, Harper \& Row Publishers, New York, NY

11. Druckman, D., Singer, J.E. \& Van Cott, H. (Eds). (1997). Enhancing Organizational Performance. Washington DC: National Academy Press.

12. Griffin, R. W. \& Ebert, R. J. (1993). Business. (3rd ed). Englewood Cliffs: Prentice Hall.

13. Holtmann, M. \& Grammling, M. (2005). Designing and Implementing Staff Incentive Schemes. 
14. Hongoro, C. \& Normand, C, (2002). Health Workers: Building and Motivating the Workforce.

15. ILO (1985). Flexible Working Time in Production, Social and Labour Bulletin, Geneva.

16. Jeffrey, S. \& Shaffer, V. (2007). The Motivational Properties of Tangible Incentives. Sage Publications.

17. Krugman, P. (1994). Defining and Measuring Productivity. Retrieved from https://www.oecd.org/std/productivity-stats/40526851.pdf

18. Lazear, E. (1999). Output-based Pay - Incentives or Sorting NBER Working Paper 7419

19. Matocchio, J. (2006) Strategic Compensation: A Human Resource Management Approach, New Jersey: Prentice Hall

20. Milgrom, P. \& Roberts, J. (1992). Economics, Organization and Management Englewood Cliffs, NJ: Prentice Hall

21. Milkovich, G.T., \& Newman, J. (2005), Compensation, New York: McGraw-Hill Companies, Inc.

22. National Productivity Council (India) (n.d, retrieved in 2015). Theory of Incentives. Retrieved from http://www.productivityinknowledgebase/general/incentives.pdf

23. Okoye, P. \& Ezejiofor, R. (2013). Effect of Human Resource Development on Organizational Productivity. International Journal of Academic Research in Business and Social Sciences 3(10) $250-268$. http://dx.doi.org/10.6007/IJARBSS/v3-i10/295

24. Perrow, C. (1986). Complex Organizations. New York: Random House

25. Pouliakas K. (2008). Pay enough, don't pay too much or don't pay at all? An empirical study of the non-monotonic impact of incentives on job satisfaction. IZA Discussion Paper No. 4713, http://papers.ssrn.com/sol3/papers.cfm?abstract_id=1545140

26. Prokopenko, J. (1992). Productivity Management: A Practical handbook. Geneva: International Labour Office.

27. Schraeder, M. \& Brecton, B. (1998). An Overview of Recent Trends in Incentive Pay Programs. The Coastal Business Journal 2(1) 18-27

28. Tongo, C.I. (2006). Incentive Factors Affecting Productivity of Public Servants in Ogun State; Evidence from Ado-Ota Local government Area. Retrieved from: http://www.ilo.org/public/english/iira/documents/congress/regional/lagos2011/istparallel/sessionk/incentive sfactor.pdf

29. Torrington, D., Hall, L. \&Taylor, S. (2008). Human Resource Management. New York: Prentice.

30. Weaver, S.J. (2008). Characteristics for success: Predicting Intervention Effectiveness with the Job Characteristics Model. Unpublished MSc dissertation, University of Central Florida, Orlando Creative Commons Attribution - Non Commercial - No Derivatives 4.0 International License. 